\title{
Effect of Different Plant Growth Regulators on Shooting of Stem Cuttings in Dragon Fruit [Hylocereus undatus (Haworth) Britton \& Rose]
}

\author{
Ayesha Siddiqua $^{1}$, D. Thippesha ${ }^{2}$, M. Venugopala Reddy ${ }^{3}$ and N. Deeksha Raj $^{4}$ \\ ${ }^{1}$ Department of Fruit science, College of Horticulture, Mudigere-577132 \\ ${ }^{2}$ Department of Horticulture, College of Agriculture, UAHS, Shivamogga-577225 \\ ${ }^{3}$ Department of Horticulture, College of Agriculture, UAS, Raichur-584104 \\ ${ }^{4}$ Department of Horticulture, College of Agriculture, UAS, Bengaluru-560 065 \\ *Corresponding author
}

\section{A B S T R A C T}

\section{Keywords}

Dragon fruit, IBA, Stem cuttings, Plant growth regulators, DAP (Days after planting)

\section{Article Info}

Accepted:

15 April 2019

Available Online:

10 May 2019

\begin{abstract}
An investigation was done to study the effect of different plant growth regulators on shooting of stem cuttings in Dragon fruit (Hylocereus undatus (Haworth) Britton \& Rose) at the Department of Horticulture, College of Agriculture, UAHS Shivamogga, during the year 2017-18. The experiment was laid out by following Complete Randomized Block Design with twelve treatments and three replications. The stem cuttings of Dragon fruit treated with different plant growth regulators result reveals that, least number of days taken for sprout initiation (7.34), maximum percentage of sprouting at 30 and 60 DAP (40.24 and $58.67 \%)$, number of sprouts per cutting at 30,60 and 90 DAP $(0.96,1.77$ and $2.43)$, length of the sprout and shoot $(2.63,8.35$ and $17.45 \mathrm{~cm})$, shoot diameter $(2.92,3.08$ and $3.53 \mathrm{~cm})$, fresh weight of the shoot $(15.49,25.66$ and $56.66 \mathrm{~g})$ dry weight of shoot $(5.19,7.81$ and $11.12 \mathrm{~g})$, root to shoot ratio $(0.22,0.57$ and 0.67$)$ respectively was recorded in cuttings treated with IBA $7000 \mathrm{ppm}$. Among the different growth regulators application of IBA $7000 \mathrm{ppm}$ was found to improve shooting of stem cuttings in Dragon fruit under low cost poly house condition.
\end{abstract}

\section{Introduction}

Dragon fruit (Hylocereus undatus (Haworth) Britton \& Rose) is popular in South East Asia. It is an edible vine cactus species belonging to the family Cactaceae which has received worldwide recognition first as an ornamental plant and then as a fruit crop. It is commonly called as Pitaya. It is one of the newly introduced exotic fruit crop in India. It is well known for its rich nutrient contents specially vitamin C, phosphorus, calcium as well as its antioxidant characteristics (Morton, 1987). It has wide range of medicinal properties like anti cancerous, prevents asthma, reduces arthritis pain, good for bone health, improves heart related problems. The common method adopted for propagation of dragon fruit is by seeds and stem cuttings. Besides, stem cuttings is the most convenient, rapid and 
simple method of plant propagation as it carries all the desirable characters of a mother plant. The information on use of growth regulators on shooting of stem cuttings in Dragon fruit is meager. Hence, the experiment is conducted to know the effect of growth regulators and their combinations on shooting of stem cuttings.

\section{Materials and Methods}

An experiment was done on the "Effect of different plant growth regulators on shooting of stem cuttings in dragon fruit [Hylocereus undatus (Haworth) Britton \& Rose]" was conducted in low cost poly house of the Department of Horticulture, College of Agriculture, UAHS Shivamogga, during the year 2017-18. The experiment was laid out in Completely Randomized Block Design with twelve treatments and three replications viz., $\mathrm{T}_{1}$-IBA (5000ppm), $\mathrm{T}_{2}$-IBA (6000ppm), $\mathrm{T}_{3^{-}}$ IBA (7000ppm), T 4 -NAA (100ppm), T $_{5}$-NAA (200ppm), $\quad \mathrm{T}_{6}$-IBA $(5000 \mathrm{ppm})+\mathrm{NAA}$ (100ppm), $\mathrm{T}_{7}$-IBA (5000ppm) + NAA (200ppm), $\mathrm{T}_{8^{-}}$IBA (6000ppm) + NAA (100ppm), T $_{9^{-}}$IBA $(6000 \mathrm{ppm})+$ NAA (200ppm), T $_{10^{-}}$IBA $(7000 \mathrm{ppm})+$ NAA (100ppm), $\mathrm{T}_{11^{-}}$IBA (7000ppm) + NAA (200ppm), $\mathrm{T}_{12}-$ control (dipped in normal water). The cuttings were treated with varied levels of growth regulators as per the treatment and planted in the poly bags filled with Soil, Sand and FYM in 2:1:1 proportion for easy rooting one basal node was buried in the medium. The planted poly bags were kept inside low cost poly house for rooting.

\section{Results and Discussion}

\section{Number of days taken for sprout initiation}

In the present investigation, influence of different plant growth regulators and their combinations have greatly influenced the days taken for sprout initiation. Significant differences were seen between auxin concentrations for days taken to first sprout. The data obtained is presented in Figure 1.

Among the different concentrations, the cuttings treated with $\left(\mathrm{T}_{3}\right)$ IBA7000ppm (7.34) took less number of days for the sprout initiation which was on par with $\left(\mathrm{T}_{2}\right)$ IBA $6000 \mathrm{ppm}$ (7.65) and ( $\left.\mathrm{T}_{1}\right)$ IBA $5000 \mathrm{ppm}$ (8.39). Significantly maximum number of days required for first sprouting (16.33) was in untreated cuttings $\left(\mathrm{T}_{12}\right)$. It could be attributed to the better utilization of reserve carbohydrates, nitrogen and other nutrients stored in stem cuttings by activation of hydrolytic enzymes (Chandramouli, 2001). Similar findings were reported by Shirol and Patil (1992) in Ixora.

\section{Percent sprouting}

The data pertaining to sprouting percentage as influenced by different concentration of growth regulators with different combination at the different stages of growth are presented in Figure 2.

The maximum percentage of sprouting at 30 and 60 DAP was recorded in cuttings treated with $\left(\mathrm{T}_{3}\right)$ IBA 7000 ppm (40.24 and 58.67\%). While, the control $\left(\mathrm{T}_{12}\right)$ recorded the minimum percentage of sprouting (9.12 and $18.25 \%)$. This might be due to the fact that auxins are known to induce stimulus for regeneration of roots by promotion of hydrolysis, mobilization and utilization of nutritional reserves in the region of root and shoot formation (Nanda, 1975). Similar results are reported by Swetha (2005) in Lavender.

\section{Number of sprouts per cutting}

The data pertaining to number of sprouts per cutting as influenced by growth regulators with different combination at the different stages of growth are presented in Figure 3. 
The maximum number of sprouts per cutting at 30, 60 and 90 DAP $(0.96,1.77$ and 2.43) was recorded in the cuttings treated with $\left(\mathrm{T}_{3}\right)$ IBA $7000 \mathrm{ppm}$. While minimum numbers of sprouts $(0.31,1.09$ and 1.41) were recorded in control $\left(\mathrm{T}_{12}\right)$. It could be perhaps due to enhancement of physiological functions in the cuttings favourably at this concentration. Earliness in sprouting, increase in number of sprouts might be due to better utilization of stored carbohydrates, nitrogen and other factors with the aid of growth regulators (Chandramouli, 2001). These results are in harmony with the outcome of Pervaiz et al., (2007) in Barbados cherry.

\section{Shoot length $(\mathrm{cm})$}

The data pertaining to length of sprout and shoot per cutting as influenced by growth regulators with different combination at the different stages of growth are presented in Figure 4. The highest shoot length at 30, 60 and 90 DAP was recorded in cuttings treated with $\left(\mathrm{T}_{3}\right)$ IBA $7000 \mathrm{ppm}(2.63,8.35$ and $17.45 \mathrm{~cm})$. While minimum length of shoots $(0.99,1.24$ and $2.93 \mathrm{~cm})$ was recorded in control $\left(\mathrm{T}_{12}\right)$. It might be ascribed to better root growth which augmented absorption and translocation of nutrients from nursery soil which take active part in various plant metabolic processes (Singh 2001). Siddiqui and Hussain (2007) reported maximum shoot length and shoot diameter with IBA 4000 ppm in Ficus hawaii.

\section{Diameter of shoot per cuttings (mm)}

The data pertaining to the diameter of shoot per cuttings as influenced by growth regulators with different combination at the different stages of growth are presented in Figure 5. The maximum diameter of shoot at 30, 60 and 90 DAP $(2.92,3.08$ and $3.53 \mathrm{~cm})$ was recorded in $\left(\mathrm{T}_{3}\right)$ IBA $7000 \mathrm{ppm}$. While minimum diameter of shoot $(1.04,1.41$ and $1.45 \mathrm{~cm})$ was recorded in control (T12). It might be due to more number of leaves and vigorous root system as a consequence of better carbohydrates production and assimilation. The results are in conformity with Upadhyay and Badyal (2007) in Pomegranate.

\section{Shoot fresh weight $(g)$}

The data on the shoot fresh weight of Dragon fruit cuttings as influenced by different concentration of growth regulators with different combination are furnished in Figure 6. The treatments differed significantly at 30 , 60 and 90 days after planting. The highest shoot fresh weight was seen in Dragon fruit cuttings treated with $\left(\mathrm{T}_{3}\right)$ IBA $7000 \mathrm{ppm}$ $(15.49,25.66$ and $56.66 \mathrm{~g})$. Lowest fresh weight was seen in (T12) control $(9.66,19.63$ and $25.52 \mathrm{~g})$. This could be due to IBA, which results in early sprouting, increase in number of leaves and leaf area and well developed shoot system. The results are in accordance with the findings of Stancato et al., (2003) in Rhipsalis.

\section{Shoot dry weight (g)}

The data on the shoot dry weight of Dragon fruit cuttings as influenced by different concentration of growth regulators with different combination are furnished in Figure 7. The treatments differed significantly at 30 , 60 and 90 days after planting.

Among the treatments highest shoot dry weight was seen in Dragon fruit cuttings treated with $\left(\mathrm{T}_{3}\right)$ IBA $7000 \mathrm{ppm}(5.19,7.81$ and $11.12 \mathrm{~g})$. The least shoot dry weight of Dragon fruit cuttings was found in $\left(\mathrm{T}_{12}\right)$ control $(1.92,3.71$ and $6.85 \mathrm{~g})$. This could be due to earliness in sprouting, increase in number of leaves and leaf area and higher shoot fresh weight. Similar results are in conformity with Shukla and Bist (1994) in Pear, Shirol and Patil (1992) in Ixora. 
Fig.1 Number of days taken for sprout initiation

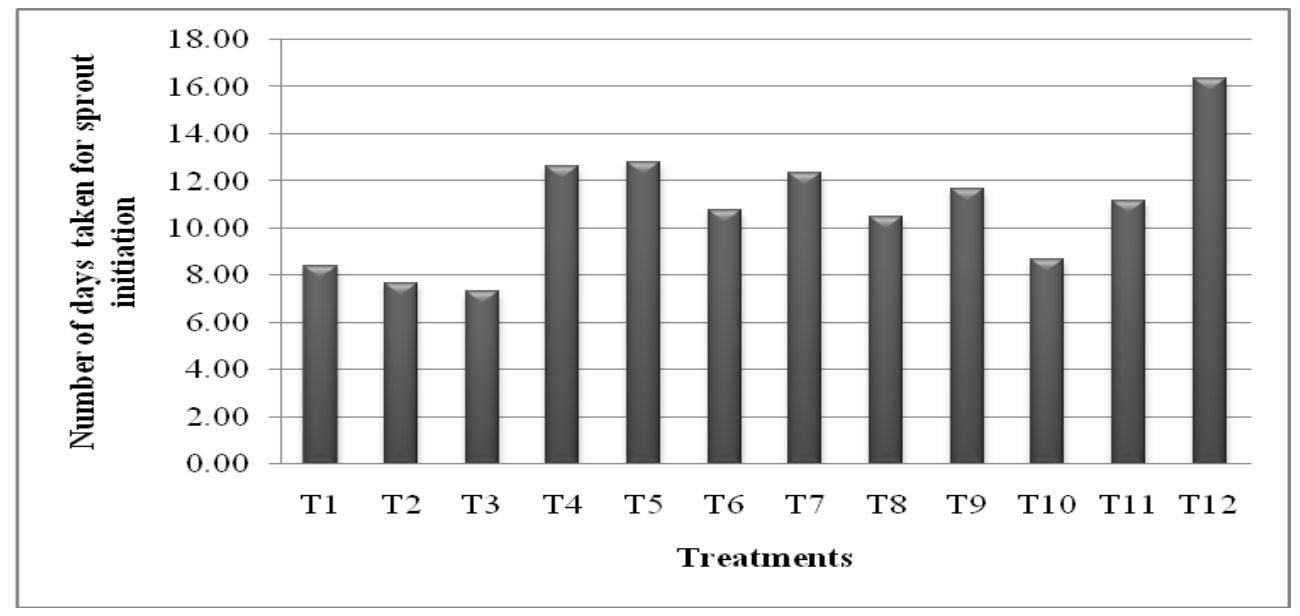

Fig.2 Percentage of cuttings sprouted at 30 and 60 DAP

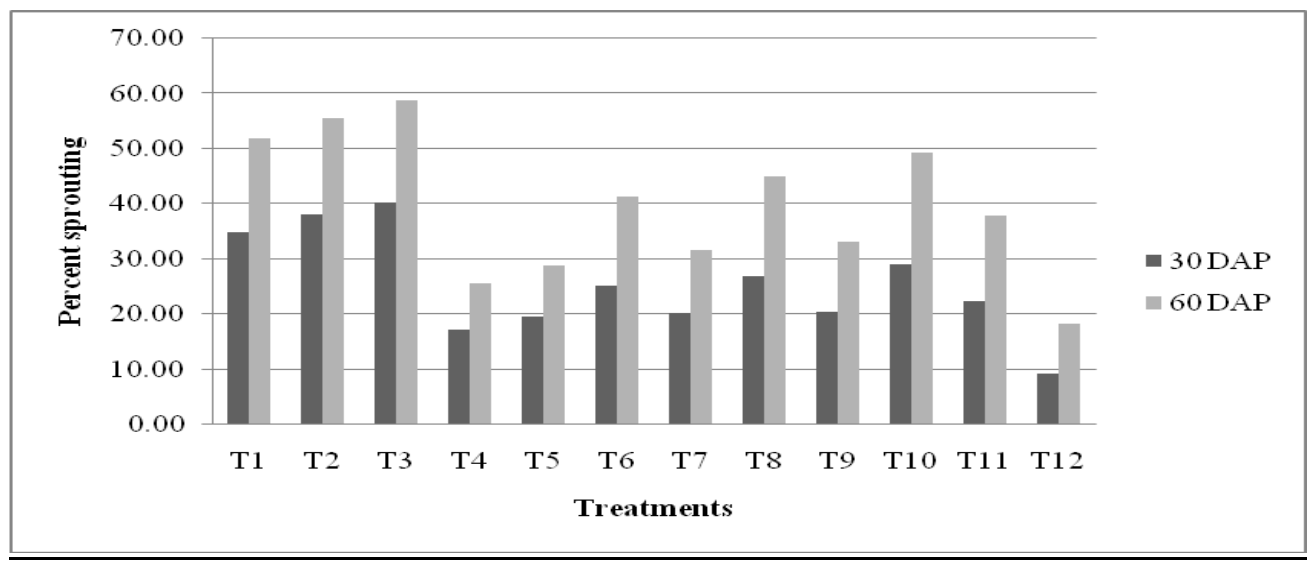

Fig.3 Number of sprouts at 30, 60 and 90 DAP

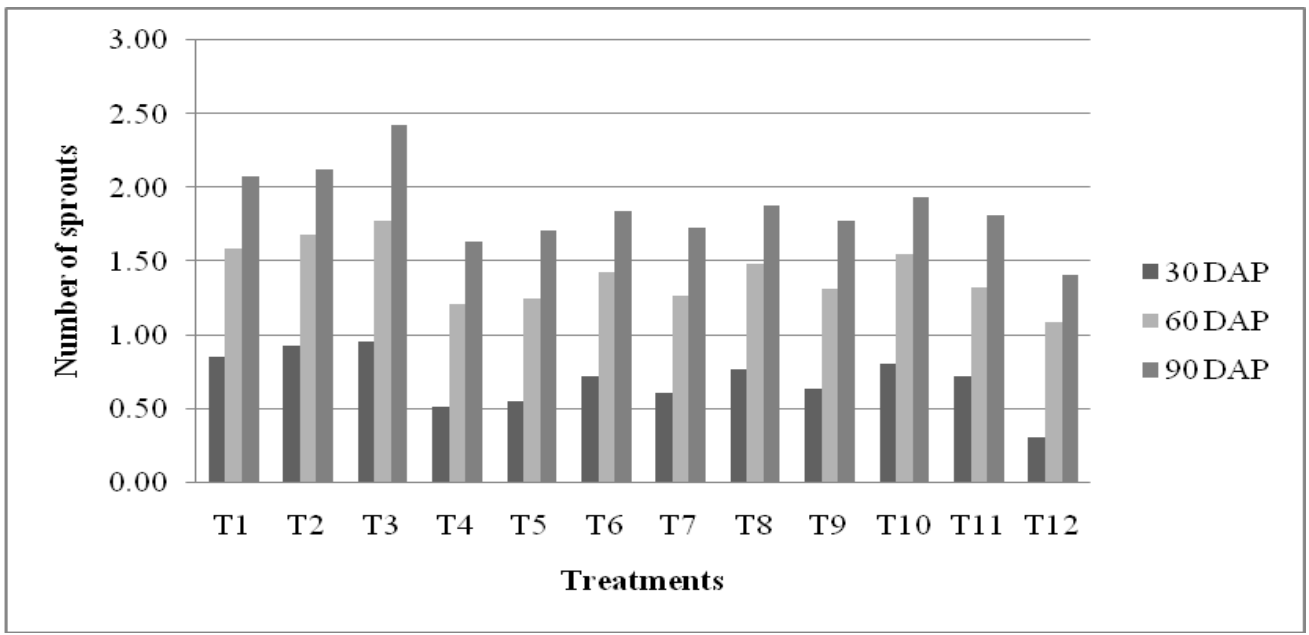


Fig.4 Length of the shoot at 30, 60 and 90 DAP

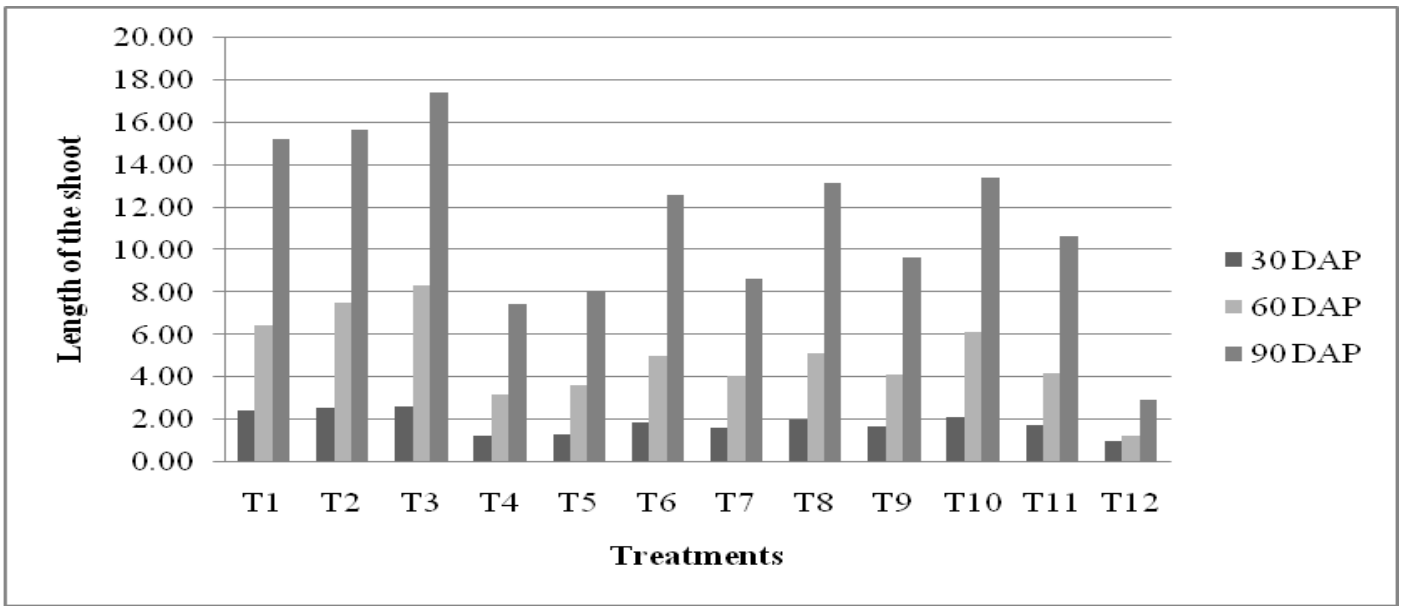

Fig.5 Shoot diameter at 30, 60 and 90 DAP

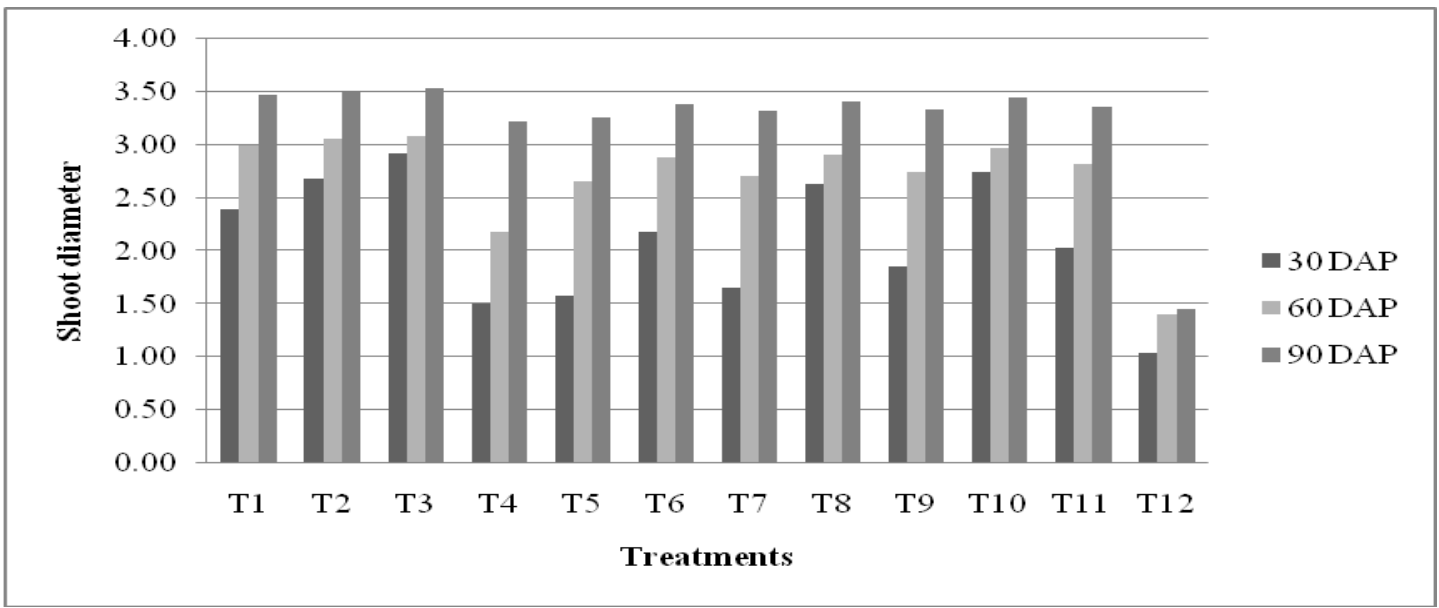

Fig.6 Shoot fresh weight at 30, 60 and 90 DAP

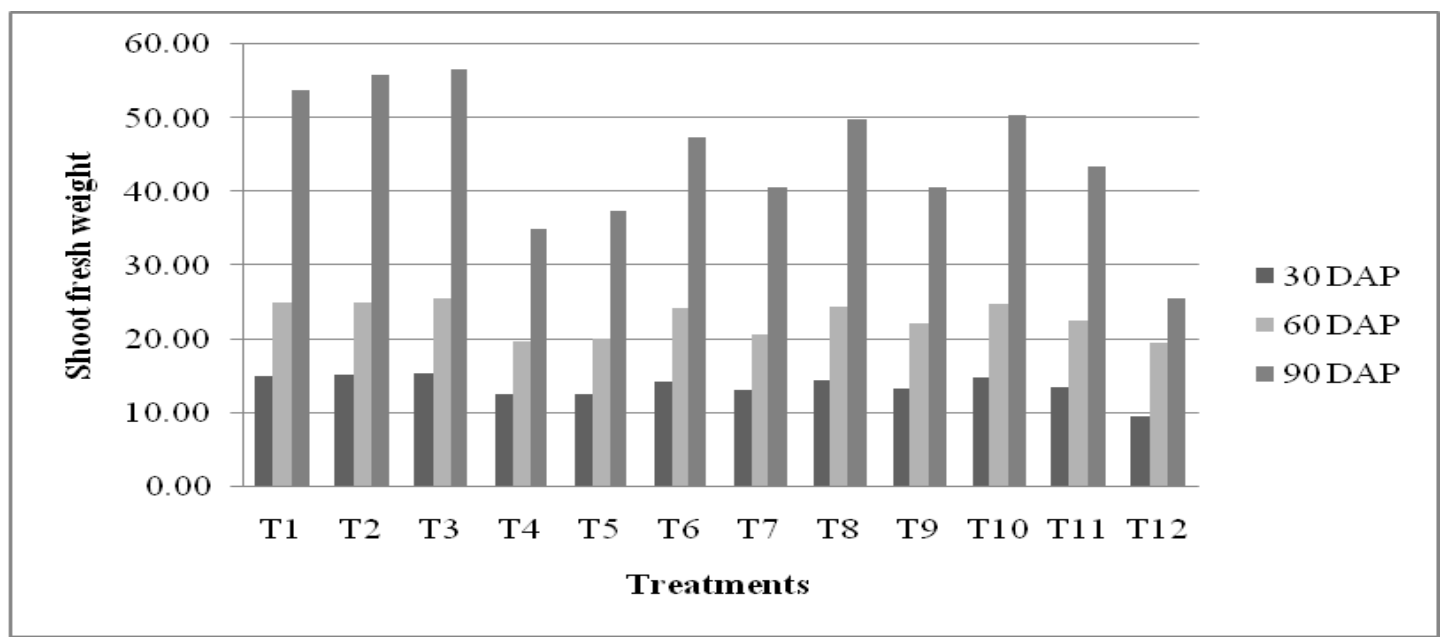


Fig.7 Shoot dry weight at 30, 60 and 90 DAP

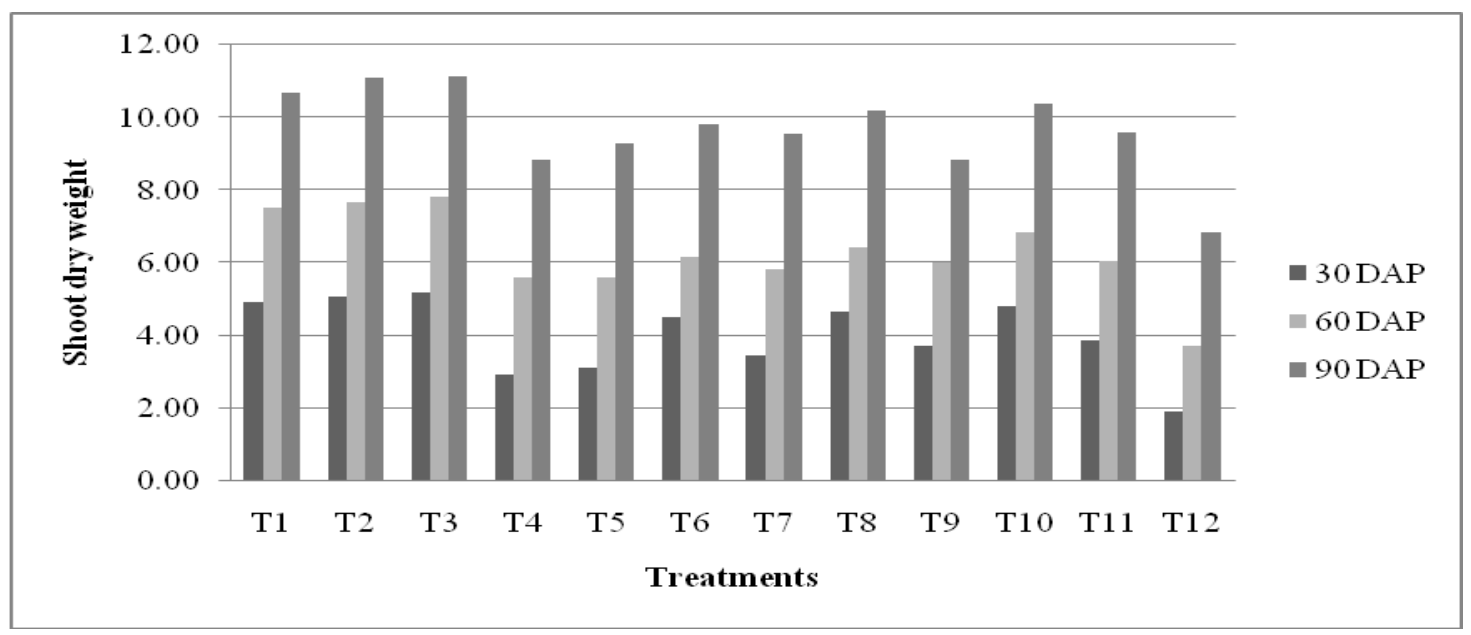

Fig.8 Root to shoot ratio at 30, 60 and 90 DAP

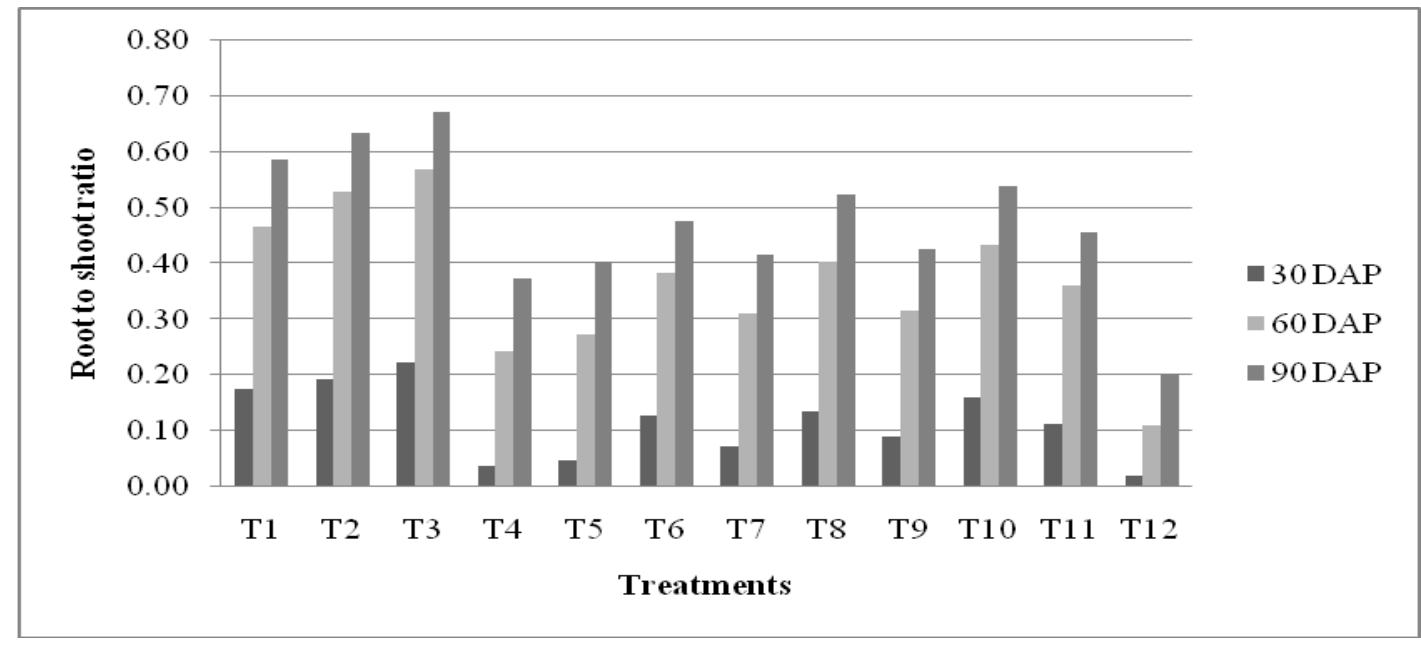

\section{Root to shoot ratio}

The data on the root to shoot ratio of Dragon fruit cuttings as influenced by different concentration of growth regulators with different combination are furnished in Figure 8. The treatments differed significantly at 30 , 60 and 90 days after planting.

The highest root to shoot ratio was seen in Dragon fruit cuttings treated with $\left(\mathrm{T}_{3}\right)$ IBA $7000 \mathrm{ppm}(0.22,0.57$ and 0.67$)$. Lowest root to shoot ratio was seen in control $(0.02,0.11$ and 0.20). The explanation for these differences probably resides in crop type, resource supply and other experimental factors. The results are in accordance with the findings of Seran and Thiresh (2015) and Rahad et al., (2016) in Dragon fruit.

In conclusion, the study revealed that application of different pant growth regulators has great potential to induce shooting in stem cuttings of dragon fruit. Among all the treatments, IBA (7000 ppm) gave best results with respect to shoot parameter followed by IBA $(6000 \mathrm{ppm})$. Based on the findings of current investigation it is recommended that 
vegetative method of propagation through stem cuttings in dragon fruit is reliable for nursery plant production as it is quick and easy method of vegetative propagation.

\section{References}

Chandramouli, H., 2001. Influence of growth regulators on the rooting of different types of cuttings in Bursera penicilliatai (DC) Engl. M.Sc. Thesis, Univ. Agric. Sci., Bangalore, Karnataka (India).

Morton, J. F., 1987. Fruits of warm climates. Strawberry Pear. Florida Flair Books, Miami. pp. 347-348.

Nanda, K. K., 1975. Physiology of adventitious root formation. Indian $J$. Pl. physiol., 18: 80-89.

Pervaiz, S., Beigh, M. A., Lone, R. A. and Nanda, A. B., 2007. Effect of plant growth regulators on rooting of Barbados cherry. The Asian J. Hort., 2(1): 152-154.

Rahad, M.K., Islam, M.A., Rahim, M.A. and Monira, S., 2016. Effects of rooting media and varieties on rooting performance of dragon fruit cuttings (Hylocereus undatus Haw.). Res. Agric. Livest. Fish. An open Access Peer Reviewed J., 3(1):67-77.

Seran, T.H. and Thiresh, A., 2015. Root and shoot growth of dragon fruit (Hylocereus undatus) stem cutting as influenced by IBA. Agric and
Biological Sci. J., 1(2): 27-30.

Shirol, A. M. and Patil, A. A., 1992. Effect of growth regulators on biochemical constituents and rooting of Ixora. Prog. Hort., 24(3-4): 152-156.

Shukla, G. S. and Bist, L. D., 1994. Studies on the efficacy of IBA and NAA on clonal propagation by cutting in low chilling pear rootstocks. Indian J. Hort., 51(4): 351-57.

Siddiqui, M. I. and Hussain, S. A., 2007. Effect of indole butyric acid and types of cuttings on root initiation of Ficus hawaii. Sarhad J. Agri., 23(4): 141-145.

Singh, A. K., 2001. Effect of auxins on rooting and survival of jasmine (Jasminum sambac Ait.) stem cuttings. Prog. Hort., 33(2): 174-177; 919-925.

Stancato, G. C., Aguiar, F. F. A., Kanashiro, S., Tavares, A. R., Catharino, E. L. M. and Silveira, R. B., 2003. Rhipsalis grandiflora Haw. (Cactaceae) propagation by stem cuttings. Scientia Agricola, 60(40): 651-656.

Swetha, H., 2005. Propagation of Indian lavender (Bursera delpechiana Poiss.) through cuttings under mist. M.Sc. (Hort.) thesis, Univ. Agric. Sci., Dharwad, Karnataka (India). p.32.

Upadhyay, S. D. and Badyal, J., 2007. Effect of growth regulators on rooting of pomegranate (Punica granatum L.) cutting. Haryana J. Hort Sci., 36 (12): $58-59$.

\section{How to cite this article:}

Ayesha Siddiqua, D. Thippesha, M. Venugopala Reddy and Deeksha Raj, N. 2019. Effect of Different Plant Growth Regulators on Shooting of Stem Cuttings in Dragon Fruit [Hylocereus undatus (Haworth) Britton \& Rose]. Int.J.Curr.Microbiol.App.Sci. 8(05): 1621-1627. doi: https://doi.org/10.20546/ijcmas.2019.805.187 